\author{
Т.Е. Сизикова, В.Н. Лебедев, В.Б. Пантюхов, Е.Ю. Вахнов, С.В. Борисевич \\ Федеральное государственное бюджетное учреждение \\ "48 Центральный научно-исследовательский институт» \\ Министерства обороны Российской Федерации, \\ 141306, Российская Федерация, г. Сергиев Посад, ул. Октябрьская, д. 11
}

\begin{abstract}
Поступила 12.03.2019 г. Принята к публикации 17.08.2019 г.
В обзоре рассмотрены особенности патогенеза экспериментальной боливийской геморрагической лихорадки (БГЛ) - болезни, вызываемой вирусом Мачупо (семейство Arenaviridae). Сделан вывод, что для проведения доклинических исследований медицинских средств защиты (МСЗ) в условиях in vivo на мелких лабораторных животных целесообразно использовать морских свинок при инфицировании штаммом Chicava или адаптированным для данных животных вариантом штамма Carvallo. Использование морских свинок в качестве мелких лабораторных животных при изучении патогенеза заболевания, вызванного вирусом Мачупо, позволяет провести статистически надежное определение количественных показателей экспериментальной инфекции и проводить отбор препаратов для заключительного этапа доклинической оценки. Поскольку аренавирусы блокируют процесс образования интерферона (ИФН) в инфицированном организме, мыши, дефектные по образованию ИФН, являются перспективными животными моделями при изучении патогенеза БГЛ и могут быть использованы для изучения аттенуированных вариантов вируса Мачупо, которые в дальнейшем могут быть рекомендованы для изучения в качестве кандидатов в живые вакцины. Яванские макаки (Macaca fascicularis) являются лабораторным животным, моделирующим патогенетические проявления БГЛ у человека. Животные этого вида могут быть использованы при проведении заключительных этапов доклинической оценки МСЗ.
\end{abstract}

Ключевые слова: аренавирусы; боливийская геморрагическая лихорадка; вирус Мачупо; грьзунь; лабораторные животные; морские свинки; мыци; низшие приматы; яванская макака.

Библиографическое описание: Сизикова Т.Е., Лебедев В.Н., Пантюхов В.Б., Вахнов Е.Ю., Борисевич С.В. Обоснование выбора лабораторной модели для доклинической оценки медиизнских средств защиты в отношении боливийской геморрагической тихорадки // Вестник войск РХБ защииты. 2019. Т. 3. № 4. С. 319-328. https://doi.org/10.35825/2587-5728-2019-3-4-319-328

Семейство Arenaviridae представляет собой большую группу РНК-содержащих вирусов, геномная РНК которых состоит из двух сегментов и обладает амбисенсной стратегией кодирования. Аренавирусы разделяют на аренавирусы Старого Света и Нового Света по географическому положению эндемичных регионов, а также по серологическим и филогенетическим критериям $[1,2]$ (рисунок 1).

Аренавирусы включают широкий спектр патогенных для человека вирусов (от вируса лимфоцитарного хориоменингита (ЛХМ) до возбудителей особо опасных вирусных геморрагических лихорадок (ВГЛ), таких как вирусы Ласса, Мачупо, Хунин, Луйо, Сэбиа, Гуанарито и Чапаре).
Филогенетическое родство не определяет патогенность возбудителя. Так, среди аренавирусов Нового Света, относящихся к клайду В, встречаются и патогенные, и непатогенные для человека аренавирусы [3]. Пять вирусов из клайда В (вирусы Мачупо, Хунин, Сэбиа, Гуанарито и Чапаре) вызывают геморрагические лихорадки [4].

Для аренавирусных геморрагических лихорадок характерны проявления геморрагического синдрома, лейкопения, тромбоцитопения, шок, лихорадка, головные боли, миалгия, тошнота, боли в животе, рвота, диарея, мукозальные и/ или конъюнктивальные петехии, тремор, эдема легких. Для лихорадки Ласса в тяжелых случаях обычны проявления гепатита, для южноамери- 


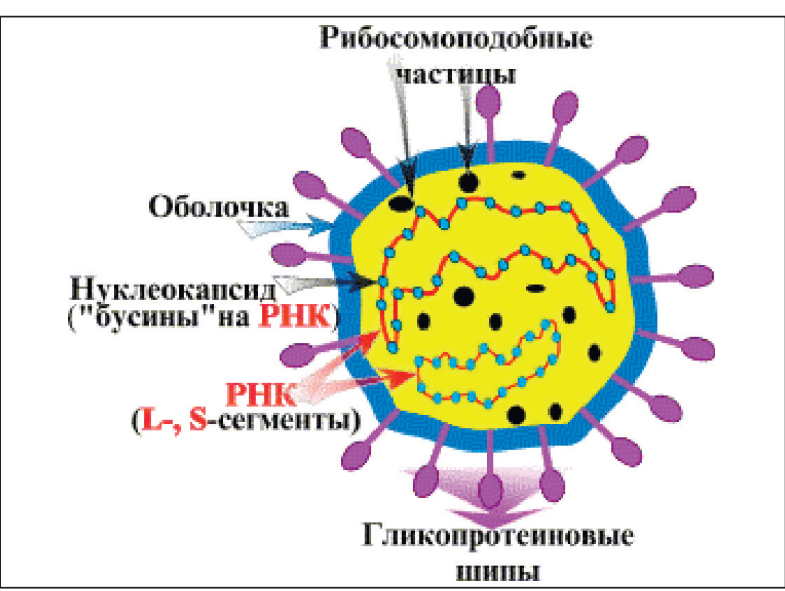

Рисунок 1 - Структура вириона аренавирусов ${ }^{1}$

Изображение взято с сайта: http://medicine-live.ru/
atlas/micro/viruses/arenavirus.htm (дата обращения:
06.02.2019) канских аренавирусных геморрагических лихорадок проявления гепатита либо отсутствуют, либо проявляются в мягкой форме. В то же время для южноамериканских аренавирусных геморрагических лихорадок более (чем при лихорадке Ласса) выражены неврологическая симптоматика, геморрагии, лейкопения и тромбоцитопения [5].

Патогенные для человека аренавирусы представляют потенциальную угрозу для здравоохранения вследствие возможности их завоза в неэндемичные регионы, поэтому актуальным является вопрос о создании медицинских средств защиты (MC3) в отношении вызываемых ими заболеваний. Перечень эффективных MC3 в отношении аренавирусных инфекций ограничен живой аттенуированной вакциной против аргентинской геморрагической лихорадки (АГЛ), широко используемой для иммунизации населения в эндемичных регионах, а также рибавирином (препарат, относящийся к классу аномальных нуклеозидов, обладающий широким спектром противовирусного действия). При лечении больных описано использование плазмы реконвалесцентов и препаратов гетерологичных иммуноглобулинов с высоким титром вируснейтрализующих антител (BНА) [6].

Разработка новых эффективных средств профилактики и лечения нового поколения (вирусные рекомбинантные вакцины, препараты на основе вирусспецифических гуманизированных моноклональных антител (МКАт) - антисмысловые олигонуклеотиды) еще далека от завершения. Поэтому исследования по созданию новых эффективных МС3 в отношении аренавирусных геморрагических лихорадок являются актуальными для здравоохранения.

Обычно используемая схема отбора препаратов для профилактики и лечения вирусных

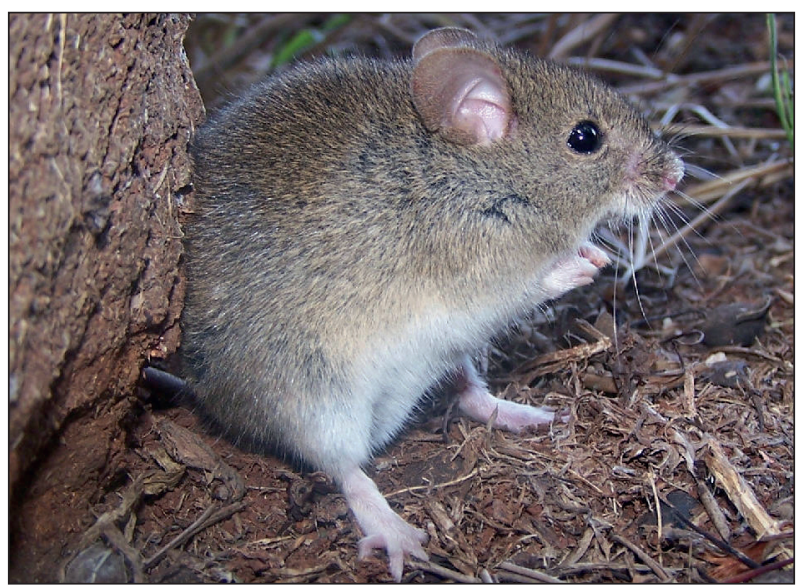

Рисунок 2 - Большая вечерняя мышь (первичный резервуар вируса Мачупо в природе) ${ }^{1}$

1 Изображение взято с сайта: http://www. faunaparaguay.com/calomyscallosus.html (дата обращения: 06.02.2019)

инфекционных заболеваний включает в себя скрининговые испытания in vitro и испытания на лабораторных животных (in vivo), адекватно моделирующие соответствующие признаки заболевания человека.

Необходимо иметь в виду, что сам факт получения положительных результатов в условиях in vitro является необходимым, но еще не достаточным для получения положительных результатов при исследованиях, проводимых в условиях in vivo. В этой связи большое значение имеют исследования на мелких лабораторных животных, которые являются важным промежуточным звеном между относительно дешевыми скрининговыми испытаниями in vitro и дорогостоящими испытаниями на низших приматах (животных, при экспериментальной инфекции аренавирусами моделирующих соответствующие признаки заболевания человека).

Цель обзора - обоснование выбора лабораторной модели для проведения доклинической оценки медицинских средств защиты в отношении боливийской геморрагической лихорадки (БГЛ).

Вирус Мачупо впервые был выделен в 1963 г. от погибшего человека. Заболевание, вызванное данным вирусом, впервые описано в 1959 г. [7-10]. Прототипным штаммом возбудителя БГЛ считается штамм Carvallo. Впервые он выделен в 1963 г. во время эпидемической вспышки БГЛ $[11,12]$. Первичным резервуаром вируса Мачупо в природе является большая вечерняя мышь Calomys callosus, рисунок 2 .

Вирус передается либо аэрозольно, либо в результате прямого контакта с инфицированной мочой, слюной или кровью грызунов. Вспышка БГЛ обычно связана с ежегодной уборкой зерновых и возникают в апреле-июле в северо-восточных районах Боливии. Их вероятной при- 
чиной является аэрогенное инфицирование вследствие вдыхания пыли, контаминированной экскрементами инфицированных вирусом Мачупо грызунов $[9,13,14]$. Вирус может также передаваться вследствие контактов больных с медра- ботниками. Такая передача вируса описана более, чем в одной вспышке БГЛ [15].

Инкубационный период при БГЛ у человека составляет от 5 до 21 сут (обычно 7-14 суток). Первые признаки заболевания включают: ли-

Таблица 1 - Клинические проявления БГЛ у низших приматов и грызунов [21-25]

\begin{tabular}{|c|c|c|c|c|c|c|c|}
\hline $\begin{array}{c}\text { Группа } \\
\text { животных }\end{array}$ & $\begin{array}{c}\text { Вид } \\
\text { животных, } \\
\text { возраст }\end{array}$ & $\begin{array}{c}\text { Способ } \\
\text { инфицирования }\end{array}$ & $\begin{array}{c}\text { Симптомы } \\
\text { заболевания }\end{array}$ & $\begin{array}{c}\text { Время } \\
\text { жизни до } \\
\text { гибели, } \\
\text { сутки п.и. }\end{array}$ & $\begin{array}{c}\text { Поздняя } \\
\text { неврологи- } \\
\text { ческая сим- } \\
\text { птоматика }\end{array}$ & $\begin{array}{c}\text { Летальность, } \\
\text { процент }\end{array}$ & $\begin{array}{c}\text { Образова- } \\
\text { ние } \\
\text { ВНА, +/- }\end{array}$ \\
\hline \multirow{5}{*}{$\begin{array}{l}\text { Низшие } \\
\text { приматы }\end{array}$} & $\begin{array}{l}\text { Мармозетки } \\
\text { (взрослые) }\end{array}$ & п/к, с/к, и/н, peros & $\begin{array}{c}\text { За 1-3 сут до } \\
\text { гибели отказ } \\
\text { от пищи. } \\
\text { Вялость, } \\
\text { слабость, } \\
\text { гипертермия }\end{array}$ & $11-21$ & Нет & 100 & - \\
\hline & $\begin{array}{c}\text { Макаки резус } \\
\text { (взрослые) }\end{array}$ & \multirow{4}{*}{$\Pi / \mathrm{k}$} & $\begin{array}{c}\text { Симптомы } \\
\text { заболевания } \\
\text { развиваются } \\
\text { через } 7 \text { сут } \\
\text { п.и. (петехии, } \\
\text { сыпь, } \\
\text { лихорадка, } \\
\text { анорексия) }\end{array}$ & $13-25$ & \multirow{4}{*}{ Есть } & 100 & + \\
\hline & $\begin{array}{c}\text { Макаки резус } \\
\text { (молодые) }\end{array}$ & & \multirow[b]{2}{*}{ То же } & 19 & & 50 & + \\
\hline & $\begin{array}{c}\text { Яванские } \\
\text { макаки (ци- } \\
\text { номолгусы) }\end{array}$ & & & 17 & & 50 & + \\
\hline & $\begin{array}{c}\text { Африканские } \\
\text { зеленые } \\
\text { мартышки }\end{array}$ & & $\begin{array}{c}\text { Лихорадка, } \\
\text { анорексия, } \\
\text { шок, } \\
\text { геморрагии, } \\
\text { пневмония }\end{array}$ & 15 & & 100 & - \\
\hline \multirow{8}{*}{ Грызуны } & $\begin{array}{c}\text { Белые мыши } \\
\text { (взрослые) }\end{array}$ & $\begin{array}{c}\text { и/ц, и/п, и/н, } \\
\text { per os }\end{array}$ & $\begin{array}{c}\text { Отсутствие } \\
\text { признаков } \\
\text { заболевания }\end{array}$ & - & \multirow{3}{*}{ Нет } & - & + \\
\hline & $\begin{array}{l}\text { Мыши- } \\
\text { сосунки }\end{array}$ & и/ц, и/р & $\begin{array}{c}\text { Тремор, } \\
\text { конвульсии }\end{array}$ & $9-16$ & & - & - \\
\hline & $\begin{array}{c}\text { Мыши } \\
\text { STAT-1 -/- }\end{array}$ & и/п, с/к & $\begin{array}{c}\text { Летаргическое } \\
\text { состояние }\end{array}$ & $\begin{array}{c}7,3 \\
10,5\end{array}$ & & - & - \\
\hline & $\begin{array}{c}\text { Мыши ИНФ } \\
\alpha \beta / \gamma \text { R -/- }\end{array}$ & \multirow{3}{*}{ и/п } & $\begin{array}{l}\text { Потеря массы } \\
\text { тела, параличи }\end{array}$ & 30 & Есть & 100 & - \\
\hline & $\begin{array}{c}\text { Морские } \\
\text { свинки } \\
\text { (взрослые) } \\
6 / п \\
\end{array}$ & & - & - & \multirow{4}{*}{ Нет } & - & + \\
\hline & $\begin{array}{c}\text { Морские } \\
\text { свинки } \\
\text { (линия С-13) } \\
\end{array}$ & & - & - & & - & - \\
\hline & $\begin{array}{c}\text { Морские } \\
\text { свинки } \\
\text { (молодые) } \\
\end{array}$ & \multirow{2}{*}{ и/ц, и/п } & - & $\begin{array}{c}- \\
(87 \%)\end{array}$ & & - & - \\
\hline & $\begin{array}{l}\text { Хомячки } \\
\text { (молодые } \\
<5 \text { суток) }\end{array}$ & & Невралгии & - & & - & - \\
\hline \multicolumn{8}{|c|}{$\begin{array}{l}\text { Примечание: } \\
\text { 1. Способы заражения: и/н-интраназально, и/ц-интрачеребрально, per os - через рот; n/к-подкожно, с/к-скарификационно; } \\
\text { и/n- интраперитонеально. } \\
\text { 2. Во всех случаях была использована инфицирующая доза } 1 \times 10^{3} \text { БОЕ на животное. } \\
\text { 3. п.и. - после инфицирования; «-»- отсутствие; «+» - наличие признака. }\end{array}$} \\
\hline
\end{tabular}




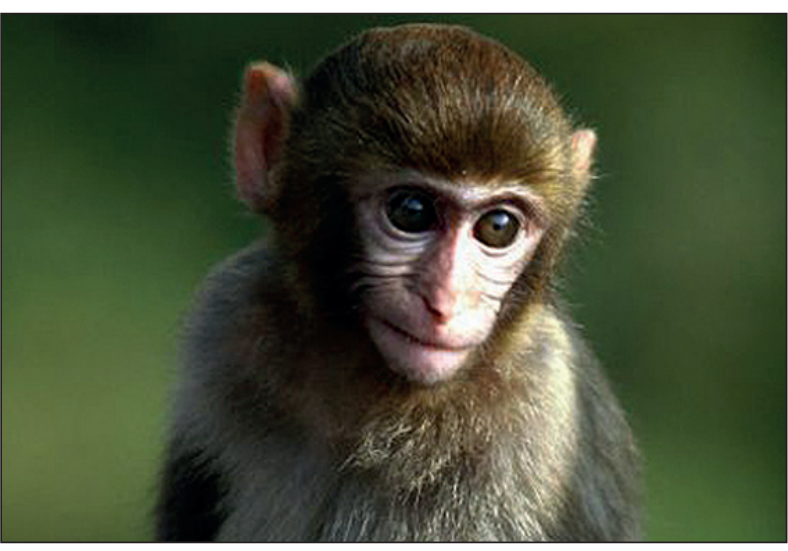

Рисунок 3 - Макака резус ${ }^{1}$

\footnotetext{
Изображение взято с сайта: http://www.poasii.ru (дата обращения: 06.02.2019)
}

хорадку, головную боль, головокружение, гипертензию, мышечные боли, боли в спине. У больных часто наблюдают петехиальную сыпь, кровотечения и конъюнктивит. Клинические проявления прогрессируют в течение 3-4 сут, у больных наблюдают рвоту, диарею, боли в животе. Клинические лабораторные анализы указывают на образование лейкопении, тромбоцитопении, протеинурии и гематурии. Во время второй недели заболевания часто проявляются геморрагические и неврологические симптомы. Неврологические симптомы включают тремор, спазматические сокращения мышц, бредовые состояния, конвульсии. Геморрагические проявления включают кровавую рвоту, носовые кровотечения, кровотечения из десен, мелену. В тяжелых случаях больные погибают на 7-12-е сут после проявления признаков заболевания [9, 13, 16-18].

Сведения о лабораторных животных, используемых в исследованиях с вирусом Мачупо, представлены в таблице 1. Они свидетельствуют о том, что в исследованиях с вирусом Мачупо используют различные виды низших приматов и грызунов. Среди животных с полноценным иммунным статусом летальные модели для вируса Мачупо (дикий тип) ограничены низшими приматами и морскими свинками [19-23].

Экспериментальная инфекция, вызываемая вирусом Мачупо, у макаков резусов Macaca mulata (рисунок 3) и яванских макак Macaca fascicularis (рисунок 4) характеризовалась тяжелым заболеванием, включающим клинические и неврологические проявления. Летальность во время этих фаз составляла соответственно 80 и $95 \%$. Попытки изменения процесса патогенеза путем декомплементации и иммунносупрессии приводили лишь к более ранней гибели животных [24].

В дальнейшем в экспериментах использовали 43 макаки резус массой 2,5-4 кг, 4 - массой 5-8 кг и 7 яванских макак массой 2-3,5 кг. Все

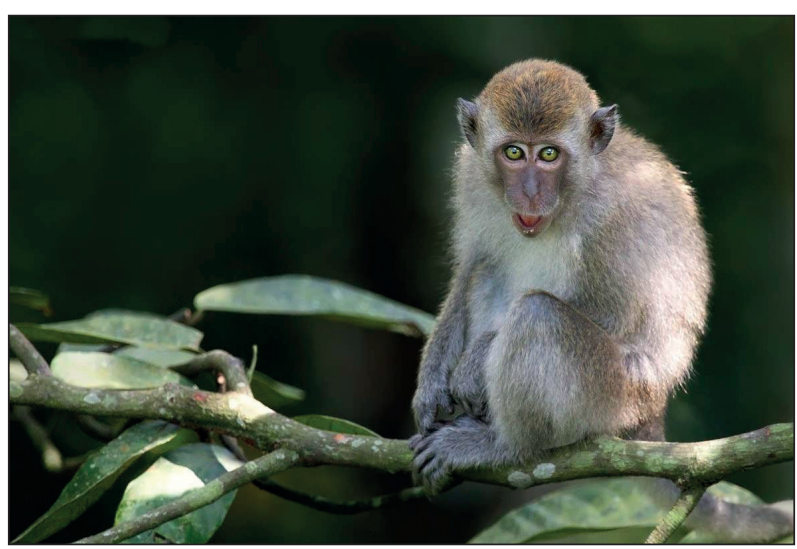

Рисунок 4 - Яванская макака

Изображение взято с сайта: http://www.poasii.ru (дата обращения: 06.02.2019)

животные были подкожно инфицированы вирусом Мачупо, штамм Carvallo, в дозе $1 \times 10^{3}$ БОЕ. Использовали культуру вируса, прошедшую 3-4 пассажа в головном мозге хомячков-сосунков [24]. У макак резус наблюдали различные клинические признаки заболевания на 6-7 сутки после инфицирования (п.и.): конъюнктивит, анорексия, лихорадка. Конъюнктивиты наблюдали в течение всего периода заболевания. Депрессия и анорексия прогрессировали по ходу развития болезни. У большинства животных с 14-х сут заболевания наблюдали отказ от пищи. У всех животных наблюдали дегидратацию, которая достигала максимума на 18-19 сут после инфицирования. Эти признаки заболевания проявлялись у всех инфицированных животных. Менее чем у 50 \% инфицированных животных наблюдали спазмы мускулатуры на 12-14 сут после инфицирования, имеющие неврологическое происхождение. Примерно у половины животных наблюдали носовые выделения, часто геморрагического характера, они утяжелялись к исходу заболевания. Гибель инфицированных животных наступала на 19-е сут после инфицирования.

Клинические признаки заболевания были более выражены у резусов, чем у яванских макак. У последних иногда наблюдали гибель без развития предшествующих клинических признаков проявления заболевания. Данные по доле выживших низших приматов после экспериментальной БГЛ при заболевании с первичными признаками и проявлениями энцефалита, представленные в таблице 2, свидетельствуют о том, что яванские макаки характеризуются несколько более высокой чувствительностью к вирусу по сравнению с макаками резус.

Результаты определения уровня вирусемии у инфицированных низших приматов, представленные в таблице 3 , свидетельствуют о том, что максимальная высота вирусемии (в крови, взятой 
Таблица 2 - Показатели выживаемости при экспериментальной инфекции у низших приматов, инфицированных вирусом Мачупо, штамм Carvallo [24]

\begin{tabular}{|c|c|c|c|c|c|}
\hline \multirow[b]{2}{*}{$\begin{array}{c}\text { Вид животных } \\
\text { (масса, кг) }\end{array}$} & \multirow[b]{2}{*}{$\begin{array}{c}\text { Количество, } \\
\text { шт. }\end{array}$} & \multicolumn{3}{|c|}{ Доля выживших, процент } & \multirow{2}{*}{$\begin{array}{c}\text { Средний срок } \\
\text { жизни до гибели, } \\
\text { сутки }\end{array}$} \\
\hline & & всего & $\begin{array}{c}\text { с первичными } \\
\text { признаками }\end{array}$ & $\begin{array}{c}\text { с } \\
\text { энцефалитами }\end{array}$ & \\
\hline Макака-резус (2,5-4,0 кг) & 43 & 19 & 14 & 5 & $19,3 \pm 5,6$ \\
\hline Макака-резус (5-8 кг) & 4 & 50 & 50 & 0 & $30,5 \pm 9,4$ \\
\hline Яванские макаки (2,0-3,5 кг) & 7 & 43 & 29 & 14 & $17,0 \pm 5,0$ \\
\hline
\end{tabular}

Таблица 3 - Показатели уровня вирусемии у низших приматов, инфицированных вирусом Мачупо, штамм Carvallo [24]

\begin{tabular}{|c|c|c|c|c|c|c|c|}
\hline \multirow{2}{*}{$\begin{array}{c}\text { Вид животных } \\
\text { (масса, кг) }\end{array}$} & \multicolumn{7}{|c|}{ Результаты определения уровня вирусемии, Ig БОЕ/мл } \\
& 4 & 5 & 7 & 10 & 14 & 17 & 21 \\
\hline Макаки-резус (2,5-4,0 кг) & - & 2,0 & 3,2 & 3,4 & 5,0 & 4,5 & 3,2 \\
\hline Яванские макаки (2,0-3,5 кг) & - & 3,0 & 3,8 & 3,3 & 3,8 & 3,6 & - \\
\hline
\end{tabular}

на 14-е сут после инфицирования) у резусов более чем на порядок превосходит соответствующий показатель у циномолгусов (5,0 и 3,8 lg БОЕ/мл).

Следовательно, имело место дифференциация видов низших приматов по уровню адекватности моделирования соответствующих признаков заболевания человека при экспериментальной инфекции. Не исключено и то, что эти различия можно объяснить за счет неравнозначности использованных количественных выборок.

T.M. Bell c coавт. [25] провели оценку яванских макаков в качестве модели для изучения инфекции, вызванной вирусом Мачупо, штамм Chicava, при внутримышечном и аэрозольном инфицировании. Данный штамм был выделен от человека, заболевание которого завершилось летальным исходом во время вспышки БГЛ в провинции Бени в 1994 г. Используемая в экспериментах культура штамма получена в результате проведения 2 пассажей в монослойной культуре клеток Vero E-6. Инкубационный период у животных составлял от 6 до 10 сут. Первыми признаками заболевания были депрессия, анорексия, умеренная лихорадка и петехиальная сыпь. За этим следовало развитие неврологических признаков, заболевание заканчивалось гибелью в среднем на 18-е сут. Анализ крови выявил лейкопению и выраженную тромбоцитопению. Биохимический анализ крови показал снижение общего белка, значительное увеличение аланин- и аспартатаминотрасфераз, умеренное увеличение щелочной фосфатазы. Спустя 10 сут п.и. выявлена макулярная сыпь, увеличение лимфатических узлов, рыхлость печени и селезенки, спорадические геморрагии желудочно-кишечного тракта (ЖКТ).
Гистологические изменения проявлялись в дегенерации и некрозах/апоптозах печени, поджелудочной железы, надпочечников, пищевода, слюнных желез, желудка, кишечника (толстого и тонкого.) Прогрессирующее воспаление в центральной нервной системе (ЦНС) гистологически выявлялось на 16-е сут п.и.

Аэрогенное инфицирование животных проведено в соответствие с ранее предложенными разработками [26-28]. Дозы при аэрогенном инфицировании были в диапазоне от 100 до 10 тыс. БОЕ [25]. При использовании инфицирующей дозы $1 \times 10^{3}$ БОЕ в первом опыте $50 \%$ животных (2 из 4) выжили. Во втором опыте при аэрогенном инфицировании были использованы дозы $1 \times 10^{2}$ и $1 \times 10^{4}$ БОЕ. Одновременно было проведено изучение заболевания в группе животных, внутримышечно инфицированных дозой $1 \times 10^{3}$ БОЕ. В данной группе признаки заболевания появились раньше, в частности вирусемия на 3 сут раньше, по сравнению с аэрогенно инфицированными животными. Однако у некоторых аэрогенно инфицированных животных наблюдали признаки заболевания (в частности фотофобию), которые не были отмечены у животных при внутримышечном инфицировании и которые характерны для заболевания человека. Авторы сделали вывод, о том, что яванские макаки адекватно моделируют БГЛ у человека, что подтверждает данные, ранее полученные G.A. Eddy с соавт. [24].

Для вируса Мачупо (как и для других патогенных для человека аренавирусов) характерно отсутствие удобной для проведения экспериментальных исследований мелкой лабораторной модели. В частности, недостаточное изучение 
патогенеза БГЛ и отсутствие лицензированных средств лечения связывают с отсутствием адекватных мелких лабораторных животных, которых можно было бы использовать при проведении доклинических исследований [29].

Необходимым условием возможности получения воспроизводимых результатов при использовании мелких лабораторных животных является их чувствительность к возбудителю, позволяющая с высоким уровнем надежности провести определение величины ЛД 50 при данном способе инфицирования. В качестве основного критерия эффективности исследуемого МС3 обычно принимают защиту не менее 70 \% экспериментальных объектов, инфицированных заведомо летальной дозой возбудителя. В качестве дополнительных критериев используют такие количественные показатели, как изменение продолжительности срока жизни до гибели инфицированных животных по сравнению с контролем (без введения препарата), изменение массы тела животных (по сравнению с данным показателем как для инфицированных, но нелеченных, так и для не инфицированных животных) [14].

Для проведения скрининга эффективных MC3 необходим поиск чувствительных к вирусу Мачупо (природным штаммам или генетически измененным вариантам) мелких лабораторных животных. Обычно в качестве таких животных используют представителей различных видов отряда грызунов. Для изучения экспериментальной инфекции, вызванной вирусом Мачупо, из мелких лабораторных животных используют различные линии морских свинок, белых мышей и хомячков.

T.M. Bell с соавт. [30] провели изучение экспериментальной инфекции, вызванной вирусом Мачупо, у морских свинок. Для аэрогенного инфицирования морских свинок был использован вирус Мачупо, штамм Chicava. Важно отметить, что в отличие от прототипного штамма Carvallo, штамм Chicava является высокопатогенным для морских свинок и не нуждается в адаптации к ним. Исходная культура штамма Carvallo не вызывает 100 \% гибель морских свинок, для адаптации необходимо проведение серийных пассажей через селезенку животных.

Установлено, что введение вируса Мачупо, штамм Chicava в дозе 1000 БОЕ при аэрогенном инфицировании морских свинок вызывало гибель 100 \% инфицированных животных. В последующих экспериментах использовали инфицирующую дозу 100 БОЕ. Данная доза вызывала гибель примерно 90 \% животных. На этом основании можно считать, что величина ЛД для морских свинок при аэрогенном инфицировании последних культурой штамма Chicava вируса Maчупо составляет примерно 10 БОЕ. Поэтому автором сделан вывод о том, что морские свинки могут быть использованы в качестве модельных животных при проведении доклинической оценки МС3. Внутрибрюшинное инфицирование морских свинок адаптированным вирусом Мачупо, штамм Carvallo, вызывало гибель $\approx 60 \%$ животных $[17,31,32]$.

J.W. Golden с соавт. [31] получили генетически измененный вариант (ГИВ) вируса Мачупо, штамм Carvallo, $\left(\mathrm{Car}^{91}\right)$, полностью аттенуированный для морских свинок. В качестве исходного для получения варианта $\mathrm{Car}^{91}$ использовали штамм Carvallo данного возбудителя. Геномный анализ исходного штамма Carvallo и варианта $\mathrm{Car}^{91}$ позволили определить нуклеотидные вариации, приводящие к аттенуации. Эти вариации сводятся: к замене у варианта $\operatorname{Car}^{91}$ в гене белка L (при сравнении кДНК геномных РНК): C на T в позиции 399; делеции в позиции 409-443 в регионе между генами L и Z; замене Т на С в позициях 1683, 2883, 2946. Поскольку изменений в S-сегментах геномных PHК не выявлено, указанные различия в структуре L-сегмента представляют единственные различия между вирулентным штаммом вируса и аттенуированным ГИВ.

Изменения в L-сегменте генома были достаточными для того, чтобы термодинамическая стабильность варианта $\operatorname{Car}^{91}$ была в 3,2 раза ниже по сравнению со штаммом Carvallo (значения $\Delta \mathrm{G}$ соответственно - 16,2 ккал/моль и 51,4 ккал/моль).

Вариант Car $^{91}$ неспособен реплицироваться в культуре клеток так же эффективно, как исходный штамм Carvallo. Исключение составляет культура клеток Vero, где уровень накопления для варианта $\operatorname{Car}^{91}$ и штамма Carvallo статистически достоверно не различается $(6,2$ и $6,5 \mathrm{lg}$ БОЕ соответственно) [31].

J.W. Golden c соавт. [31] проведено сравнение варианта $\mathrm{Car}^{91}$ с исходным вирусом Мачупо, штамм Carvallo и штаммом Chicava данного возбудителя. Каждой исследуемой вируссодержащей культурой внутрибрюшинно инфицировали по 8 морских свинок (заражающая доза $1 \times 10^{3}$ БОЕ). Наблюдали гибель животных, изменение их массы и наличие у них лихорадки. Следует отметить, что по количеству вирионов, стоящих за 1 БОЕ, исследуемые ГИВ и штаммы вируса Мачупо отличались друг от друга. Для штамма Chicava этот показатель составлял 13, для штамма Carvallo 26 , для варианта $\mathrm{Car}^{91}-369$ (различия по сравнению со штаммом Carvallo примерно в 14 раз).

у всех животных, инфицированных штаммом Chicava, в промежуток между 8 и 20 сутками п.и. отмечена лихорадка, но только у одной была зарегистрирована температура выше $41^{\circ} \mathrm{C}$. Все животные к 24-м сут п.и. погибли. У животных, инфицированных штаммом Carvallo, наблюдали снижение массы тела между 9 и 21 сут, но повышенной температуры (выше $39,5^{\circ} \mathrm{C}$ ) не было зарегистрировано ни у одной из них. Пять из 
8 инфицированных животных погибли (летальность $62,5 \%$ ). В отличие от штамма Chicava, у трех морских свинок, инфицированных штаммом Carvallo, развились параличи, животные подверглись эвтаназии на 21-е сут. Трое выживших животных восстановили сниженную на 9-21-е сут п.и. массу тела к 30-м сут п.и. Средний срок жизни до гибели для штаммов Chicava и Carvallo составил 22 и 23,5 сут соответственно.

У животных, инфицированных вирусом Мачупо, вариант Car $^{91}$, признаки заболевания отсутствовали. Различия по летальности между штаммами Chicava и Carvallo были статистически недостоверны $(P=0,1331)$, различия по этому показателю между вариантом $\mathrm{Car}^{91}$ и штаммом Carvallo были статистически достоверны $(\mathrm{P}=0,0082)$. Различия по снижению массы тела между всеми исследуемыми в опыте вариантами были статистически недостоверны. Максимальный уровень вирусемии для штамма Chicava составил 1088 БОЕ/мл, для штамма Carvallo 166 БОЕ/мл (вирусемия выявлена только у одного животного). У животных, инфицированных вариантом $\operatorname{Car}^{91}$, вирусемия не была выявлена [31].

Анализ сывороток животных, инфицированных вариантом Car $^{91}$ вируса Мачупо, взятых на 30-е сут п.и., установил, что у 6 животных из 8 в ИФА были выявлены антитела в титре 1:600. В реакции нейтрализации ВНА были выявлены у всех животных, причем у тех двух животных, у которых в ИФА вирусспецифические антитела не были выявлены, расчетные значения $\mathrm{T}_{50}$ и $\mathrm{T}_{80}$ (обратные величины титра ВНА, обеспечивающие 50 и 80 \% нейтрализацию вируса), составляли 269 и 59,5 соответственно [31].

J.W. Golden c coaвт. [31] также изучена возможность использования варианта $\operatorname{Car}^{91}$ в качестве аттенуированной вакцины, для обеспечения защиты от заболевания, вызванного гетерологичными аренавирусами Нового Света. Была испытана возможность защиты указанным вариантом морских свинок при разрешении иммунитета вирусом Гуанарито (возбудитель Венесуэльской геморрагической лихорадки). Спустя 45 сут после иммунизации вариантом $\operatorname{Car}^{91}$ в дозе $1 \times 10^{3}$ БОЕ морские свинки были инфицированы вирусом Гуанарито (доза $2 \times 10^{3}$ БОЕ). Оценивали показатели гибели, снижения массы тела и лихорадки в течение 25 сут п.и. У контрольных (неиммунизированных вариантом $\operatorname{Car}^{91}$ ) морских свинок снижение массы тела началось с 6-х сут п.и. на фоне лихорадки. Все контрольные животные погибли (средний срок жизни до гибели - 16 сут). В группе иммунизированных морских свинок погибло только одно животное из 8 (на 17-е сут п.и.). У погибшего животного так же наблюдали снижение массы на фоне умеренной лихорадки $\left(40,3^{\circ} \mathrm{C}\right)$.

Полученные результаты свидетельствуют о том, что иммунизация морских свинок вари- антом $\mathrm{Car}^{91}$ вируса Мачупо обеспечивает защиту от гетерологичного вируса Гуанарито, причем эта защита происходит в отсутствие значимых значений тиров ВНА к последнему возбудителю [31].

Следовательно, использование морских свинок в качестве лабораторных животных при изучении патогенеза заболевания, вызванного вирусом Мачупо, позволяет провести статистически надежное определение количественных показателей экспериментальной инфекции.

Если одним из основных этапов при использовании морских свинок для изучения патогенеза заболевания, вызванного вирусом Мачупо, как правило, является получение адаптированного для данных животных варианта возбудителя, то при использовании для этой цели белых мышей доминирующим направлением является подбор чувствительных к вирусу Мачупо генетически модифицированных линий животных.

Установлено, что Z-белок аренавирусов Нового Света связывает белок, индуцируемый геном 1 ретиноловой кислоты (RIG1), и, таким образом, блокирует образование интерферона (ИФН) $\beta$ [33]. Кроме того, нуклеопротеин вируса Мачупо блокирует ядерную транслокацию ИФН-регулирующего фактора-3 (ИРФ-3) и ингибирует активацию промоторов, зависимых от ИРФ-3 и ИФН $\beta$ [34]. Полученные результаты согласуются с тем, что тип I ИФН-ответа может быть критичным для контроля БГЛ. Таким образом, мыши дефектные по образованию ИФН, являются перспективными мелкими лабораторными животными при изучении патогенеза БГЛ.

S.B. Bradfute с соавт. [29] изучили чувствительность белых мышей STAT-1, дефектных по сигналу трансдукции и активатору транскрипции, к инфицированию вирусом Мачупо, штамм Carvallo (дикий тип). Вирус прошел 3-4 пассажа в головном мозге хомячков-сосунков и затем 2 пассажа в клетках Vero. Мышей инфицировали внутрибрюшинно, подкожно и интраназально.

При внутрибрюшинном инфицировании зарегистрирована 100 \% гибель животных. Средний срок гибели п.и. составлял 7,3 сут. При подкожном инфицировании была зарегистрирована 70 \% гибель, средний срок гибели п.и. составлял 10,5 сут. При интраназальном инфицировании соответствующие показатели 30 \% и 19 сут.

Спустя 3-е сут п.и. вирус в низких титрах $\left(1 \times 10^{2}\right.$ БОЕ/мл) был выявлен в селезенке и почках. К 5-7 сут вирус распространился во все органы, его максимальный титр достигал значений от $1 \times 10^{5}$ до $1 \times 10^{7}$ БОЕ/г (БОЕ/мл для плазмы крови). В плазме крови концентрация вируса на 5-е сут составляла $2 \times 10^{6}$ БОЕ/мл, на 7-е сут - $2 \times 10^{7}$ БОЕ/ мл. В ходе развития инфекции было зарегистрировано значительное возрастание уровня белых кровяных телец. Уровень тромбоцитов снизился 
к 5-м сут п.и., а к 7-м сут произошло восстановление исходного уровня.

Так же, как и в экспериментах на морских свинках, в опытах на белых мышах установлены детерминанты вирулентности на молекулярном уровне. Показано, что вирус Мачупо с единственной аминокислотной заменой (фенилаланин вместо изолейцина в позиции 438 в трансмембранной области гликопротеина GP2) является аттенуированным для белых мышей, в том числе и для дефектных по образованию $\alpha, \beta, \gamma$ ИФН. Однако данный вариант генетически нестабилен, поскольку при проведении дальнейших пассажей в морских свинках происходит возврат к вирусу «дикого типа» [35]. Для родственного вирусу Мачупо вируса Хунин показано, что аналогичная замена в позиции 437 приводит к аттенуации возбудителя для мышей-сосунков. ГИВ вируса Мачупо, экспрессирующий GPC вируса Хунин, штамм Candid 1, был стабильным, высокоаттенуированным и иммуногенным, что доказано в опытах на белых мышах [35].

В дальнейшем было установлено, что данный ГИВ, утративший нейротропизм для экспериментальных лабораторных животных, был авирулентен для низших приматов, морских свинок, мышей. Использование хомячков-сосунков в исследованиях, проводимых с вирусом Мачупо, ограничено их применением в качестве дополнительной системы накопления возбудителя [29].

Таким образом, по результатам исследований установлено, что яванские макаки является лабораторным животным, моделирующим патогенетические проявления БГЛ у человека. Животные этого вида могут быть использованы при проведении заключительных этапов доклинической оценки МС3.

Для проведения стадии доклинических исследований в условиях in vivo на мелких лабораторных животных целесообразно использовать морских свинок при инфицировании штаммом Chicava или адаптированным для данных животных вариантом штамма Carvallo. Полученные результаты позволят проводить отбор препаратов для заключительного этапа доклинической оценки. Генетически модифицированные линии белых мышей могут быть использованы для изучения аттенуированных вариантов вируса Мачупо, которые в дальнейшем могут быть рекомендованы для изучения в качестве кандидатов в живые вакцины.

\section{Информация о конфликте интересов}

Авторы заявляют, что исследования проводились при отсутствии любых коммерческих или финансовых отношений, которые могли бы быть истолкованы как потенциальный конфликт интересов.

\section{Сведения о рецензировании}

Статья прошла открытое рецензирование двумя рецензентами, специалистами в данной области. Рецензии находятся в редакции журнала.

\section{Список источников}

1. McLay L., Ansary A., Liang Y., Ly H. Targeting virulence mechanisms for the prevention and therapy of arenaviral hemorrhagic fever // Antiviral Res. 2013. V. 97. № 2. P. 81-92. https://doi.org/10.1016/j.antiviral.2012.12.003

2. Radoshitzky S.R., Bao Y., Buchmeier M.J. et al. Past, present and future of arenavirus taxonomy // Arch. Virol. 2015. V. 160. № 7. P. 1851-1874. https://doi.org/10.1007/s00705015-2418-y

3. Abraham J., Kwong J.A., Albarino C.C. et al. Hostspecies transferring receptor 1 orthologs are cellular receptors for nonpathogenic New World Clade B arenaviruses // PLos Pathog. 2009. V. 5. № 4. P. 1-10. https://doi.org/10.1371/journal. ppat.1000358

4. Milazzo M.L., Campbell G.L., Fulhorst C.F. Novel arenavirus infection in humans, US // Emerg. Infect. Dis. 2011. V. 17. № 8. P. 1417-1420. https://doi.org/10.3201/eid1708.110285

5. Shao J., Liang Y., Ly H. Human hemorrhagic fever causing arenaviruses: molecular mechanisms contributing to virus virulence and disease pathogenesis // Pathogens. 2015. V. 4. P. 283-306.

6. Sayburn A. WHO gives go ahead for experimental treatments to be used in Ebola outbreak // BMJ. 2014. V.349. P. 1.
7. Charrel R.N., de Lamballerie X. Arenaviruses other than Lassa virus // Antiviral Res. 2003. V. 57. № 1-2. P. 89-100.

8. Johnson K.M. Epidemiology of Machupo virus infection. 3. Significance of virological observations in man and animals // Am. J. Trop. Med. Hyg. 1965. V. 14. № 5. P. 816-818.

9. Mackenzie R.B., Beye H.K., Valverde L., Garron H. Epidemic hemorrhagic fever in Bolivia. I. A preliminary report of the epidemiologic and clinical findings in a new epidemic area in South America // Am. J. Trop. Med. Hyg. 1964. V. 13. P. 620-625.

10. Radoshitzky S.R., Jahrling P.B., Bavari S. Bolivian hemorrhagic fever / Eds Singh S.K., Ruzek D. Viral hemorrhagic fevers. Boca Raton, FL: CRC Press, 2014. P. 339-358.

11. Golden J.W., Hammerbeck C.D., Mucker E.M., Brocato R.L. Animal models for the study of rodent-borne hemorrhagic fever viruses: Arenaviruses and Hantaviruses // Biomed. Res. Int. 2015. V. 2015. P. 793257. https://doi. org/10.1155/2015/793257

12. Johnson K.M., Wiebenga N.H., Mackenzie R.B. et al. Virus isolations from human cases of hemorrhagic fever in Bolivia // Proc. Soc. Exp. Biol. Med. 1965. V. 118. P. 113-118. 
https://doi.org/10.3181/00379727-118-29772

13. Aguilar P.V., Camargo W., Vargas J. et al. Reemergence of Bolivian hemorrhagic fever, 2007-2008 // Emerg. Infect. Dis. 2009. V. 15. № 9. P. 1526-1528. https://doi. org/10.3201/eid1509.090017

14. Radoshitzky S.R., Kuhn J.H., de Kok-Mercado F. et al. Drug discovery technologies and strategies for Machupo virus and other New World arenaviruses // Expert. Opin. Drug Discov. 2012. V. 7. № 7. P. 613-632. https://doi.org/10.151 7/17460441.2012.687719

15. Buchmeier M.J., De la Torre J.C., Peters C.J. // In: Feilds Virology. V. 2. / Eds. Knipe D.M., Howley P.M. Lippencott: Williams and Wilkins, 2013. P. 1283-1303.

16. Centers for Disease Control and Prevention. Bolivian hemorrhagic fever: El Beni Department, Bolivia, 1994 // JAMA. 1995. V. 273. № 3. P. 194-196.

17. Peters C.J., Kuehne R.W., Mercado R.R. et al. Hemorrhagic fever in Cochabamba, Bolivia, 1971 // Am. J. Epidemiol. 1974. V. 99. № 6. P. 425-433.

18. Tesh R.B. Viral hemorrhagic fevers of South America // Biomedica. 2002. V. 22. № 3. P. 287-295.

19. Kastello M.D., Eddy G.A., Kuehne R.W. A rhesus monkey model for the study of Bolivian hemorrhagic fever // J. Infect. Dis. 1976. V. 133. № 1. P. 57-62.

20. Khmelev A.L., Borisevich I.V., Pantiukhov V.B. et al. Use of guinea pigs to evaluate the efficacy of a heterological immunoglobulin against Bolivian hemorrhagic fever // Vopr. Virusol. 2009. V. 54. № 4. P. 42-44.

21. Terrell T.G., Stookey J.L., Eddy G.A., Kastello M.D. Pathology of Bolivian hemorrhagic fever in the rhesus monkey // Am. J. Pathol. 1973. V. 73. № 2. P. 477-494.

22. Wagner F.S., Eddy G.A., Brand O.M. The African green monkey as an alternate primate host for studying Machupo virus infection // Am. J. Trop. Med. Hyg. 1977. V.26.№ 1.P.159-162.https://doi.org/10.4269/ajtmh.1977.26.159

23. Webb P.A., Justines G., Johnson K.M. Infection of wild and laboratory animals with Machupo and Latino viruses // Bull. World Health Organ. 1975. V. 52. № 4-6. P. 493-499.

24. Eddy G.A., Scott S.K., Wagner F.S., Brand O.M. Pathogenesis of Machupo virus infection in primates // Bull. World Health Organ. 1975. V. 52. № 4-6. P. 517-521.

25. Bell T.M., Shaia C.I., Bunton T.E. et al. Pathology of experimental Machupo virus infection, Chicava strain, in Cynomolgus macaques (Macaca fascicularis) by intramuscular and aerosol exposure // Vet. Pathol. 2015. V. 52. № 1. P. 26-37. https://doi.org/10.1177/0300985814540544

26. Dabisch P.A., Kline J., Lewis C. Characterization of a head-only aerosol exposure system for nonhuman primates // Inhal. Toxicol. 2010. V. 22. № 3. P. 224-233. https://doi. org/10.3109/08958370903191023

27. Hartings J.M., Roy C.J. The automated bioaerosol exposure system: preclinical platform development and a respiratory dosimetry application with nonhuman primates // J. Pharmacol. Toxicol. Methods. 2004. V. 49. № 1. P. 39-55. https://doi.org/10.1016/j.vascn.2003.07.001

28. Roy C.J. Reed D.S., Hutt J.A. Aerobiology and inhalation exposure to biological select agents and toxins // Vet. Pathol. 2010. V. 47. № 5. P. 779-789. https://doi. org/10.1177/0300985810378650

29. Bradfute S.B., Stuthman K.S., Shurtleff A.C., Bavari S. A STAT-1 knockout mouse model for Machupo virus pathogenesis // Virol. J. 2011. V. 8. P. 300. https://doi. org/10.1186/1743-422X-8-300

30. Bell T.M., Bunton T.E., Shaia C.I. et al. Pathogenesis of Bolivian Hemorrhagic fever in Guinea Pigs // Vet. Pathol. 2016. V. 53. № 1. P. 190-199. https://doi. org/10.1177/0300985815588609

31. Golden J.W., Beitzel B., Ladner J.T. et al. An attenuated Machupo virus with a disrupted L-segment intergenic region protects guinea pigs against lethal Guanarito virus infection // Sci. Rep. 2017. V. 7. P. 4679. https://doi.org/10.1038/s41598-017-04889-x

32. Weissenbacher M.C. Coto C.E., Calello M.A. Crossprotection between Tacaribe complex viruses. Presence of neutralizing antibodies against Junin virus (Argentine hemorrhagic fever) in guinea pigs infected with Tacaribe virus // Intervirology. 1975-1976. V. 6. № 1. P. 42-49. https://doi. org/10.1159/000149452

33. Fan L. Briese T., Lipkin W.I. Z proteins of New World arenaviruses bind RIG-I and interfere with type I interferon induction // J. Virol. 2010. V. 84. № 4. P. 17851791. https://doi.org/10.1128/JVI.01362-09

34. Martínez-Sobrido L., Giannakas P., Cubitt B. et al. Differential inhibition of type I interferon induction by arenavirus nucleoproteins // J. Virol. 2007. V. 81. № 22. P. 12696-12703. https://doi.org/10.1128/jvi.00882-07

35. Koma T., Patterson M., Huang C. et al. Virus Expressing GPC of the Candid\#1 Vaccine Strain of Junin Virus Is Highly Attenuated and Immunogenic // J. Virol. 2015. V. 90. № 3. P. 1290-1297. https://doi.org/10.1128/jvi.02615-15

\section{Об авторах}

Федеральное государственное бюджетное учреждение «48 Центральный научно-исследовательский институт» Министерства обороны Российской Федерации, 141306, г. Сергиев Посад, ул. Октябрьская, д. 11. Сизикова Татьяна Евгеньевна. Научный сотрудник, канд. биол. наук.

Лебедев Виталий Николаевич. Ведущий научный сотрудник, д-р биол. наук, проф.

Пантюхов Владимир Борисович. Начальник научно-исследовательского управления, канд. мед. наук.

Вахнов Евгений Юрьевич. Заместитель начальника отдела биологической защиты управления начальника войск РХБЗ ВС РФ, канд. мед. наук.

Борисевич Сергей Владимирович. Начальник института ФГБУ «48 ЦНИИ» МО РФ д-р. биол. наук, проф., чл.-корр. РАН.

Контактная информация для всехавторов: 48cnii@mil.ru Контактное лицо: Борисевич Сергей Владимирович; 48cnii@mil.ru 


\title{
Validation of Choice of Laboratory Model for Preclinical Estimation of Medical Protectors Against Bolivian Hemorrhagic Fever
}

\author{
T.E. Sizikova, V.N. Lebedev, V.B. Pantukhov, E.Y. Vakhnov, S.V. Borisevich \\ Federal State Budgetary Establishment "48 Central Scientific Research Institute» of the \\ Ministry of the Defence of the Russian Federation, Oktyabrskiy Street 11, Sergiev Posad \\ 141306, Russian Federation
}

\begin{abstract}
This review is dedicated to the peculiarities of pathogenesis of the experimental Bolivian hemorrhagic fever (BHF) - the disease, caused by Machupo virus (Arenaviridae family). The authors come to the conclusion that for carrying out preclinical researches of the medical means of protection (MMP) in vivo on small laboratory animals it is expedient to use guinea pigs, infected with a strain of Chicava or with a variant of Carvallo strain, adapted for these animals. The use of guinea pigs as small laboratory animals when studying pathogenesis of the disease caused by Machupo virus allows to carry out statistically reliable definition of quantitative indices of an experimental infection and to select medicines for the final stage of preclinical assessment. As arenaviruses block the process of formation of interferon (IFN) in the infected organism, mice, defective by IFN formation, are the perspective animal models for the study of BHF pathogenesis and may be used for the study of attenuated variants of Machupo virus. The Javanese macaques (Macaca fascicularis) are the laboratory animals, modeling the pathogenetic manifestations of BHF in humans. They can be used when carrying out the final stages of preclinical assessment of means of medical protection.
\end{abstract}

Keywords: arenaviruses; Bolivian hemorrhagic fever; Machupo virus; rodents; laboratory animals; guinea pigs; mice; nonhuman primates; Macaque fascicularis.

For citation: Sizikova T.E., Lebedev V.N., Pantukhov V.B., Vakhnov E.Y., Borisevich S.V. Validation of Choice of Laboratory Model for Preclinical Estimation of Medical Protectors Against Bolivian Hemorrhagic Fever // Journal of NBC Protection Corps. 2019. V. 3. № 4. P. 319-328. https://doi.org/10.35825/25875728-2019-3-4-319-328

Conflict of interest statement

The authors declare that the research was conducted in the absence of any commercial or financial relationship that could be construed as a potential conflict of interest.

Peer review information

The article has been peer reviewed by two experts in the respective field. Peer reviews are available from the Editorial Board.

References

See P. 326-327.

Authors

Federal State Budgetary Establishment «48 Central Scientific Research Institute» of the Ministry of the Defence of the Russian Federation. Oktyabrskiy Street 11, Sergiev Posad 141306, Russian Federation.

Tatyana Eugenievna Sizikova. Researcher. Candidate of Biological Sciences.

Vitaly Nikolayevich Lebedev. Leading Researcher. Doctor of Biological Sciences, Professor.

Vladimir Borisovich Pantukhov. Head of the Scientific Research Department.Candidate of Biological Sciences.

Eugeny Iurievich Vakhnov. Deputy Head of the Biological Defence Department of the Office of the Head of NBC Protection Troops. Candidate of Medical Sciences.

Sergey Vladimirovich Borisevich. Head of the FSBE «48 Central Scientific Research Institute». Doctor of Biological Sciences, Corresponding Member of RAS.

Contact information for all authors: 48cnii@mil.ru Contact person: Sergey Vladimirovich Borisevich; 48cnii@mil.ru 